\title{
Effect of Black and Green Tea on Experimental Sodium Oxalate- Induced Nephrotoxicity in Adult Male Mice
}

\author{
Hussein M. Ibrahim ${ }^{1,3}$, Abd El Ghany A. Moustafa ${ }^{2,3}$, Hassan A. Elgebaly \\ Original $\quad{ }^{1}$ Department of Anatomy and Embryology, Faculty of Medicine, Ain Shams University \\ ${ }^{2}$ Department of Histology, Faculty of Medicine, Al-Azhar University \\ ${ }^{3}$ Department of Clinical Laboratory Sciences, College of Applied Medical Sciences, Jouf \\ University \\ ${ }^{4}$ Department of Biology, College of Sciences, Jouf University
}

Article

\begin{abstract}
Background: Oxalate is a frequent component in foods from plant origin. Extraordinary concentrations of oxalate in urine leads to several renal pathological disorders. Green tea and black tea have several beneficial effects attributed to their polyphenols which act as metal chelators and scavengers of free radicals.

Aim: The present study aimed to clarify the possible ameliorating impact of black and green tea on renal tissue damage caused by oxalate.

Material and Methods: Thirty male mice were divided into six groups: Group I (control), Group II were injected with sodium oxalate, group IIIwere fed with black tea extract and group IV were fed with black tea extract and injected with sodium oxalate, group V were fed with green tea extract and group VI were fed with green tea extract and injected with sodium oxalate. The black or green tea extracts were given orally for 10 days $(2 \mathrm{ml} / 100 \mathrm{~g} /$ day $)$. Sodium oxalate $(100 \mathrm{mg} / \mathrm{kg})$ were injected as a single intraperitoneal dose at the 11 th day and animals sacrificed $12 \mathrm{~h}$ later. At the end of experiment, blood samples and kidney specimenswere obtained from all groups. Serum urea and creatinine analysis were done. The renal tissue sections were stained with H\&E and PAS stains and examined. Immunohistochemical investigation for iNOS and NF- $\mathrm{KB}$ and morphometric analysis were also implemented.

Results:Microscopically, the examined kidneys in oxalate group revealed degenerated and necrotic tubular cells ,tubular dilatation, protein casts and translucent oxalate crystals and interrupted tubular brush border and basal laminae. Furthermore, serum urea and creatinine were elevated and iNOS and NF- $\kappa B$ immunoreaction were highly positive. The aforementioned changes were reversed in group IVand VI.

Conclusion: Black and green tea extracts could protect against oxalate-induced nephrotoxicity due to their antioxidant characters.
\end{abstract}

Received: 08 November 2018, Accepted: 23 December 2018

Key Words: Black tea, green tea, immunohistochemistry, nephrotoxicity, oxalate.

Corresponding Author: Hussein Mohamed Ibrahim, MD, Department of Anatomy and Embryology, Faculty of Medicine, Ain Shams University, Cairo, Egypt, Tel.: +966 558829744, E-mail: huseinmoh76@gmail.com

ISSN: $1110-0559$, Vol. 42, No. 2

\section{INTRODUCTION}

Oxalate is a natural metabolic product and it is the conjugate base of oxalic acid. At high concentrations, oxalate can cause death in animals and less commonly in humans via its destructive influences on tissue cells ${ }^{[1]}$. Oxalate is a frequent component in foods from plant origin such as vegetables, fruits, grains, legumes, and nuts ${ }^{[2]}$

Oxalate compounds, in the average range, are harmlessly excreted from the body through the kidneys ${ }^{[3]}$ On the other hand, at extraordinary concentrations, oxalate aggregates leads to several pathological disorders such as hyperoxaluria, nephrocalcinosisand nephrolithiasis ${ }^{[4]}$. Calcium oxalate crystals, when assembled, can be held in various parts of the urinary tract, resulting in blockage of the renal tubules, damage to different varieties of cells in the renal tubular, glomerular and interstitial compartments , and disturbance of cellular functions that leads to kidney injury, inflammation and impaired renal function,damage and end-stage renal disease $\mathrm{e}^{[5]}$.

Tea extracts are added to dietary supplements due to the increasing attention to the health profits of tea. The favorable effects of tea are due to its content of catechins. They are powerful scavengers of reactive oxygen species. They may also act indirectly as antioxidants through their influences on the enzyme causing the oxidation state and certain transcription factors ${ }^{[6]}$. Urinary stones formation, particularly oxalate stones, may be suppressed by green tea consumption. The suppressing impact of green tea on 
stone formation is most probably due to its anti-oxidative outcomes ${ }^{[7]}$. Furthermore, some records reinforced the inverse correlation between tea and coffee consumption and renal stones ${ }^{[8-10]}$. Although the well-known health benefits of black and green tea due to their antioxidant components, relatively few studies were done to clarify the possible ameliorating impact of black and green tea on renal tissue damage caused by oxalate. Therefore, the aim of the present study was to investigate the biochemical and morphological changes in the mice kidneys after injection by sodium oxalate and to evaluate the effect of black and green tea pretreatment.

\section{MATERIALS AND METHODS}

\section{Animals}

30 male adult albino mice $(25-30 \mathrm{~g})$ were obtained from Jouf University animal house. The mice were maintained under convenient conditions (temperature $22 \pm 2{ }^{\circ} \mathrm{C}$, lights on at $6: 30 \mathrm{AM}$ to $6: 30 \mathrm{PM}$ hours) with free access to water and food. The animals' health was evaluated by clinical examination before the experimental period. All procedures of the experiment were carried out according to the guide rules of the Ethics Committee of Jouf University, Aljouf, Saudi Arabia. After 7 days of acclimatization to their surroundings, the mice were placed individually in the experimental cages and permitted to move freely inside.

\section{Chemicals}

Urea, and creatinine kits were obtained from Randox, UK. Sodium oxalate was acquired from Sigma Chemical Co., USA. All other chemicals were of analytical grade.

\section{Preparation of water extract of tea}

Processed black tea and green tea powder (Lipton, Unilever United States.) was obtained from a local market in Aljouf. 25 grams of tea (blackor green) was immersed in $100 \mathrm{ml}$ of boiling water. Filtering was done after 5 minutes and the filtrate was fed orally to mice at a temperature of $37 \pm 2{ }^{\circ} \mathrm{C}^{[11,12]}$.

\section{Experiment procedure}

Mice were divided randomly into six groups with 5 mice in each group. water.

Group I (control group): were received tap drinking

Group II( oxalate group): were given $100 \mathrm{mg} / \mathrm{kg}$ of sodium oxalate intraperitoneally at $11^{\text {th }}$ day of experiment and sacrificed $12 \mathrm{~h}$ later.

Group III( black tea group): were fed daily with $2 \mathrm{ml} / 100 \mathrm{~g}$ body weight per day of black tea extract orally by gastric tube to ensure that all the mice received a constant supplementation of the tea extract.

Group IV (black tea plus oxalate group): were fed daily with $2 \mathrm{ml} / 100 \mathrm{~g}$ body weight per day of black tea extract orally by gastric tube. At the 11 th day, the mice in that group were given $100 \mathrm{mg} / \mathrm{kg}$ of sodium oxalate intraperitoneally and sacrificed 12 hours later.

Group V( green tea group): were fed daily with $2 \mathrm{ml} / 100 \mathrm{~g}$ body weight per day of green tea extract orally by gastric tube.

Group VI (green tea plus oxalate group): were fed daily with $2 \mathrm{ml} / 100 \mathrm{~g}$ body weight per day of green tea extract orally by gastric tube. At the 11th day, the mice in that group were given $100 \mathrm{mg} / \mathrm{kg}$ of sodium oxalate intraperitoneally and sacrificed $12 \mathrm{~h}$ later ${ }^{[13,14]}$.

At the 11th day, Mice from all groups were anesthetized and sacrificed. Their kidneys were obtained and blood samples were drained from the heart for biochemical assessment of serum creatinine and urea.

\section{A) Histological study}

The kidneys removed from the mice of each group were weighed and kept in buffered formol saline $10 \%$. Processing for paraffin blocks was implemented and five micron sections were prepared from the paraffin fixed blocks of both kidneys. Staining of the sections with hematoxylin-eosin and Periodic acid-Schiff (PAS) stain was done ${ }^{[15]}$.

\section{B) Immunohistochemical study}

4 micron sections were prepared from the paraffin blocks of the six groups. Deparaffinization was done followed by rehydration.Endogenous peroxidases were inactivated by $\mathrm{H}_{2} \mathrm{O}_{2}$ in methanol. Subsequently, incubation for 10 minutes with $10 \%$ goat serum to block unspecific coupling was performed. Later, Sections were incubated for 12 hours with the specific primary antibodies (for iNOS and NF- $\mathrm{KB}$ antibodies, Dako, USA). Horseradish peroxidase labeled secondary antibodies was added followed by Di-aminobenzidinetetrahydrochloride solution. Counterstaining of the sections with hematoxylin was done after adequate soaking in distilled water ${ }^{[16]}$.The slides were examined and photographed using an Olympus digital microscope (Olympus BX 41TF,Tokyo,Japan ) attached to a computer system (DP2-BSWsoft ware, Olympus Corporation).

\section{C) Morphometric study}

Oxalate crystals in renal tubules were counted in 10 microscopic fields of H\&E slides of each group ${ }^{[17]}$. Similarly, the immunostained sections were examined using an Olympus DP2-BSW Image computer system (Olympus Imaging System., Tokyo, Japan), and ImagePro Plus program (version 4.5.1.27) was utilized to get morphometric data. 10 non-overlapping fields in slides of each group were analyzed for quantitative morphometric measurement of the area percentage of iNOS and NF-

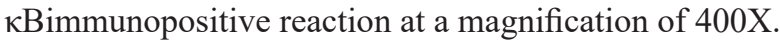

\section{D) Biochemical study}

Determination of creatinine and urea was done using modified Jaffe's ${ }^{[18]}$ and Urease Berthelot's method, respectively ${ }^{[19]}$. 


\section{E) Statistical analysis}

Statistical analysis was performed using SPSS (version 20) program. Results were represented as mean \pm standard deviation and all statistical comparisons were made by means of the one-way ANOVA test analysis. P value $<0.05$ was regarded significant.

\section{RESULTS}

\section{A) Histological study}

\section{Hematoxylin and eosin stain}

Histological examination of kidneys of control, black tea and green tea groups showed normal histological structure of renal glomeruli and tubules (Fig. 1 A). Kidneys of mice intoxicated with a single dose of sodium oxalate revealed marked tubular damage in the form of either hydropic degeneration or necrosis, tubular dilatation, protein casts and deposition of translucent oxalate crystals of different shapes which are predominantly intraluminal .The degenerative changes where in the form of fine eosinophilic granules and vacuoles in the cytoplasm of renal tubular epithelium. The renal glomeruli appeared normal(Fig. 1 B). Examination of kidneys of mice that were intoxicated with a single dose of sodium oxalate and pre-treated with black tea extract orally showed that most of the tubular cells were healthy but some of them still had pyknotic nuclei and deeply eosinophilic cytoplasm i.e. cellular necrosis. The intra-luminal oxalate crystals and intertubular congestion were also present (Fig. 1 C). Kidneys of mice intoxicated with a single dose of sodium oxalate and pre-treated with green tea extract orally showed a nearly normal histological structure apart from mild congestion of intertubular blood vessels. The oxalate crystals couldn't be seen in the lumina of renal tubules (Fig.1 D).

\section{Periodic acid-Schiff (PAS) stain}

Examination of PAS stained sections of control mice showed that the renal tubules had intact brush border and clear basal laminae (Fig. 2A). Sections from oxalate group showed partial or complete loss of the brush border in most of the tubules. Thetubular basal laminae were interrupted at many sites (Fig. 2B). Sections from the groups intoxicated with oxalate and pretreaed with either black or green tea revealed that the brush border was preserved with continuous clear basal laminae in nearly all renal tubules (Figs. 2C and D ).

\section{B) Immunohistochemistry for iNOS and NF- $\mathrm{BB}$}

Immunohistochemical investigation for iNOS and $N F-\kappa B$ revealed negative reactions in the control, black tea and green tea groups (Figs. 3A, B, C and 4A,B,C). Moreover, a highly positive reaction was seen in the renal tubular cells of oxalate intoxicated mice in the form of dark brown cytoplasmic reaction in sections stained for iNOS and dark brown nuclear reaction in sections stained for NF-kB (Figs. 3D and 4D). Black tea pretreatment reduced the immune-reaction in the renal tubular cells in oxalate intoxicated mice (Figs. 3E and 4E).Marked reduction in the immune - reaction in the renal tubular cells was also seen in the sections of mice that were intoxicated with oxalate and pretreated with green tea (Figs. 3F and 4F).

\section{C) Morphometric study}

The mean number of oxalate deposits (crystals) in sections of kidney in the group of mice intoxicated with sodium oxalate was $9.70 \pm 2.06$ which was significantly more than control group, $P<0.05$. Meanwhile, the mean number of deposits in sections of kidneys in group of mice that were intoxicated with a single dose of sodium oxalate and pre-treated with black tea was $4.70 \pm 1.89$ and in group of mice that were intoxicated with a single dose of sodium oxalate and pre-treated with green tea was $0.90 \pm 1.10$ that were both significantly lower than the group of mice intoxicated with sodium oxalate, $P<0.05$ (Histogram1).

Measuring the area percentage of iNOS and NF- $\kappa B$ immune- reaction demonstrated a significant increase in the immune- reaction in the sections of oxalate group compared with the control group. Additionally, a significant reduction in the area percentage of the immune-reaction was observed in the sections of the groups of black tea plus oxalate and green tea plus oxalate as compared to the oxalate group (Table 1 and Histogram 2).

\section{D) Biochemical study}

Intraperitoneal injection of sodium oxalate in a dose $100 \mathrm{mg} / \mathrm{kg}$ body weight to mice caused nephrotoxicity manifested by significant $(P<0.05)$ increases in serum levels of urea and creatinine when compared with the normal (negative) control group. Oral pre-treatment with the extracts of black tea and green tea to oxalate intoxicated mice induced significant $(P<0.05)$ decreases in the serum levels of urea and creatinine when compared with oxalate -intoxicated mice ( oxalate group) as depicted in Table 2 and histogram 3 and 4. 

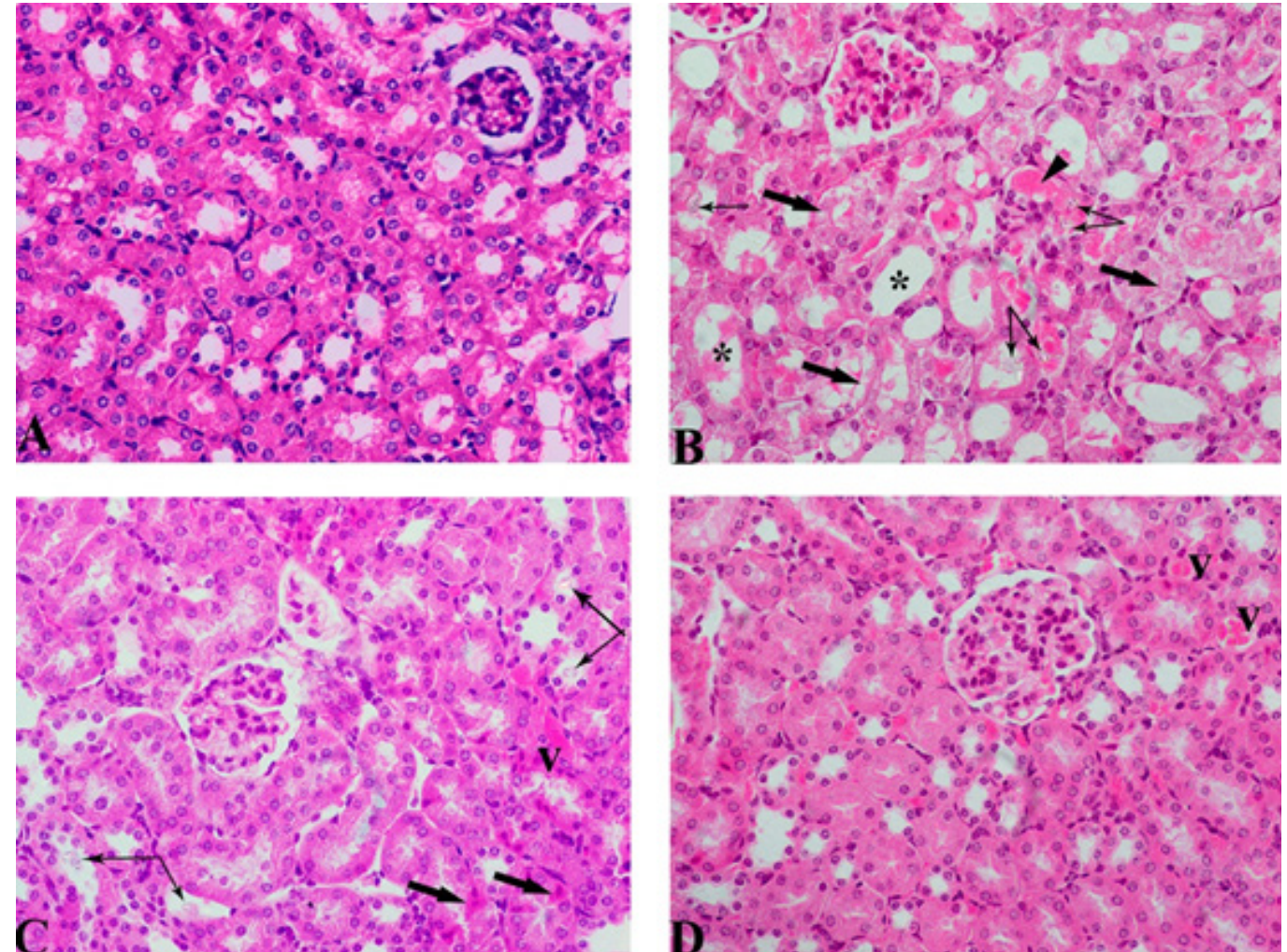

Fig. 1: Photomicrgraphs of renal sections of albino mice A) showing normal histological structure in the kidney of a control mouse. B) degenerated and necrotic tubular cells (thick arrow),tubular dilatation (*),protein casts(arrow head) and translucent oxalate crystals (thin arrow) in a kidney of oxalate intoxicated mouse.C) healthy renal tubules with some congested blood vessels(V), some areas still showing necrosis ( thick arrow)and translucent oxalate crystals(thin arrow) in a mouse kidney of black tea plus oxalate group. D) a nearly normal structure apart from some intertubular congestion (V) in a kidney a mouse from the green tea plus oxalate group.

(H \& E stain $\mathrm{x} 400)$
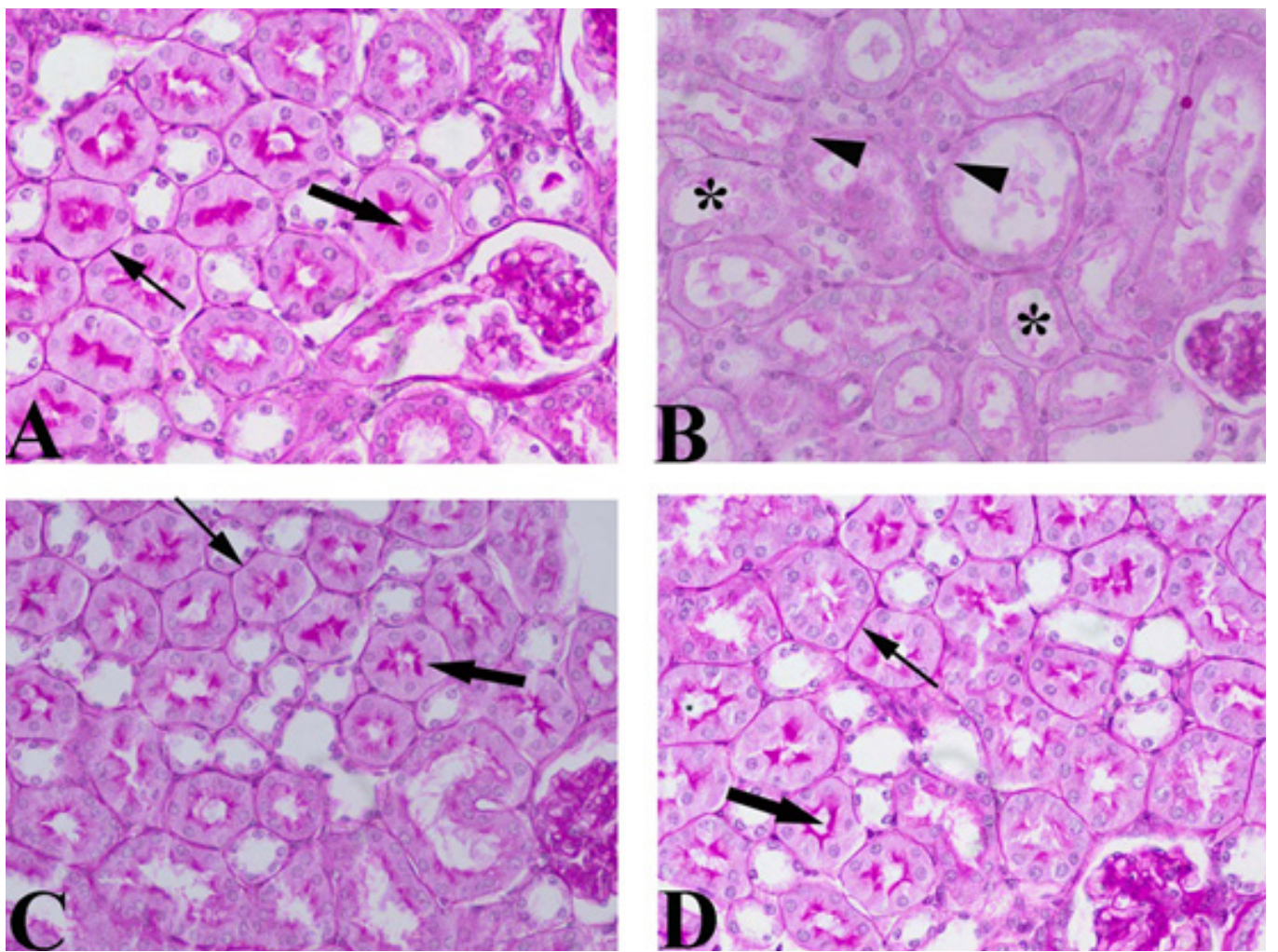

Fig. 2: Photomicrgraphs of renal sections of albino mice A) a section of control group shows many tubules with intact brush border (thick arrow) and clear basal laminae (thin arrow). B, a section of oxalate group shows partial or complete loss of brush border in most of the tubules (*), the tubular basal laminae are interrupted at many sites (arrow heads). C) a section of oxalate plus black tea and D) oxalate plus green tea group show many cortical tubules with preserved brush border (thick arrow) and continuous clear basal laminae (thin arrow) in nearly all the tubules.

(PAS stain $\mathrm{x} 400)$ 

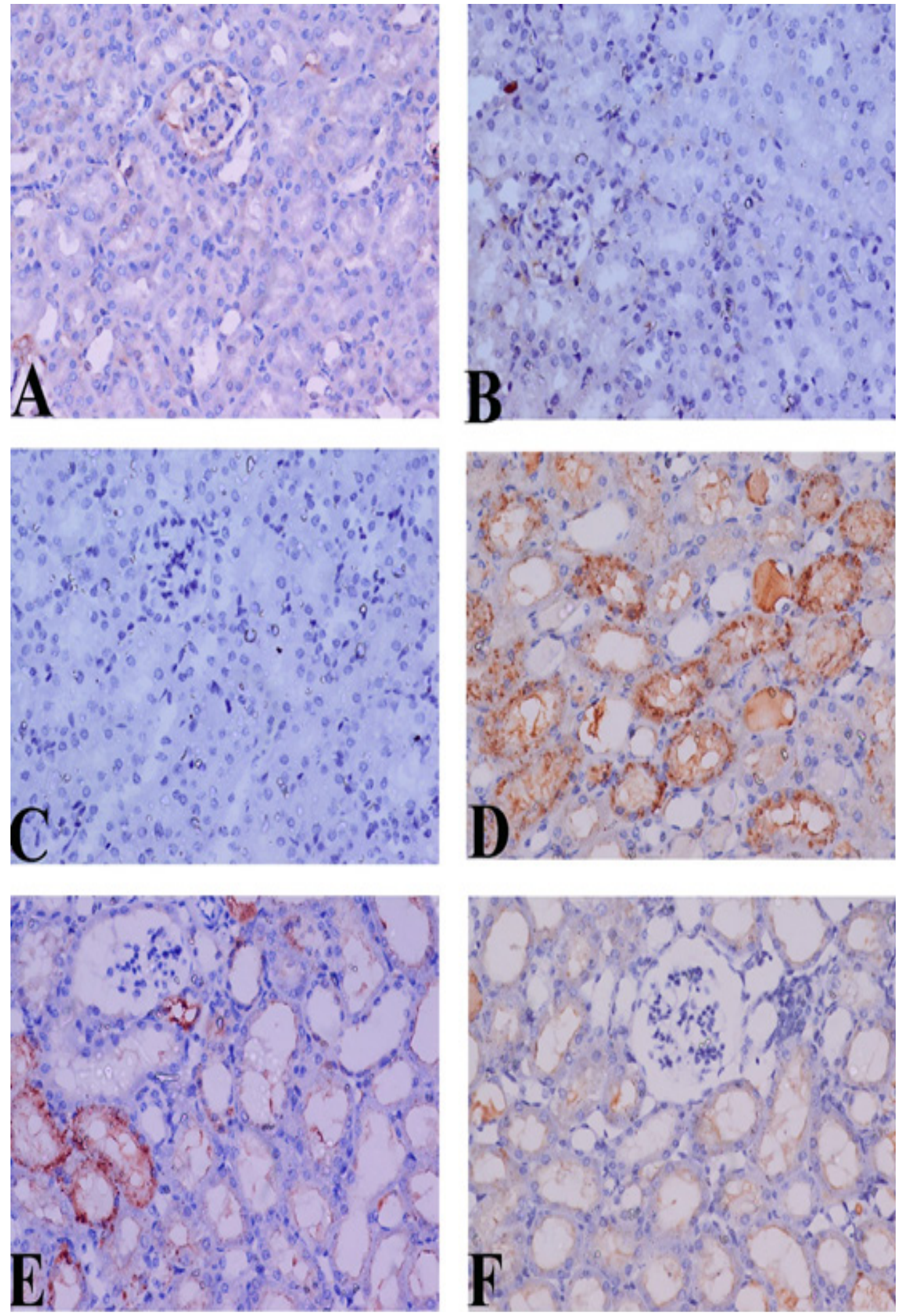

Fig. 3: Photomicrgraphs of renal sections of albino mice A) a section of control group. B) a section of black tea group C) a section or green tea groupD) a section of oxalate group shows a highly positive reaction ( dark brown colour) in the renal tubular cells. E) a section of oxalate plus black tea shows a reduction in the immune - reaction in the renal tubular cells and F) a section of oxalate plus green tea group shows a very weak reaction in the renal tubular cells.

( Immunostaing for iNOS x400) 

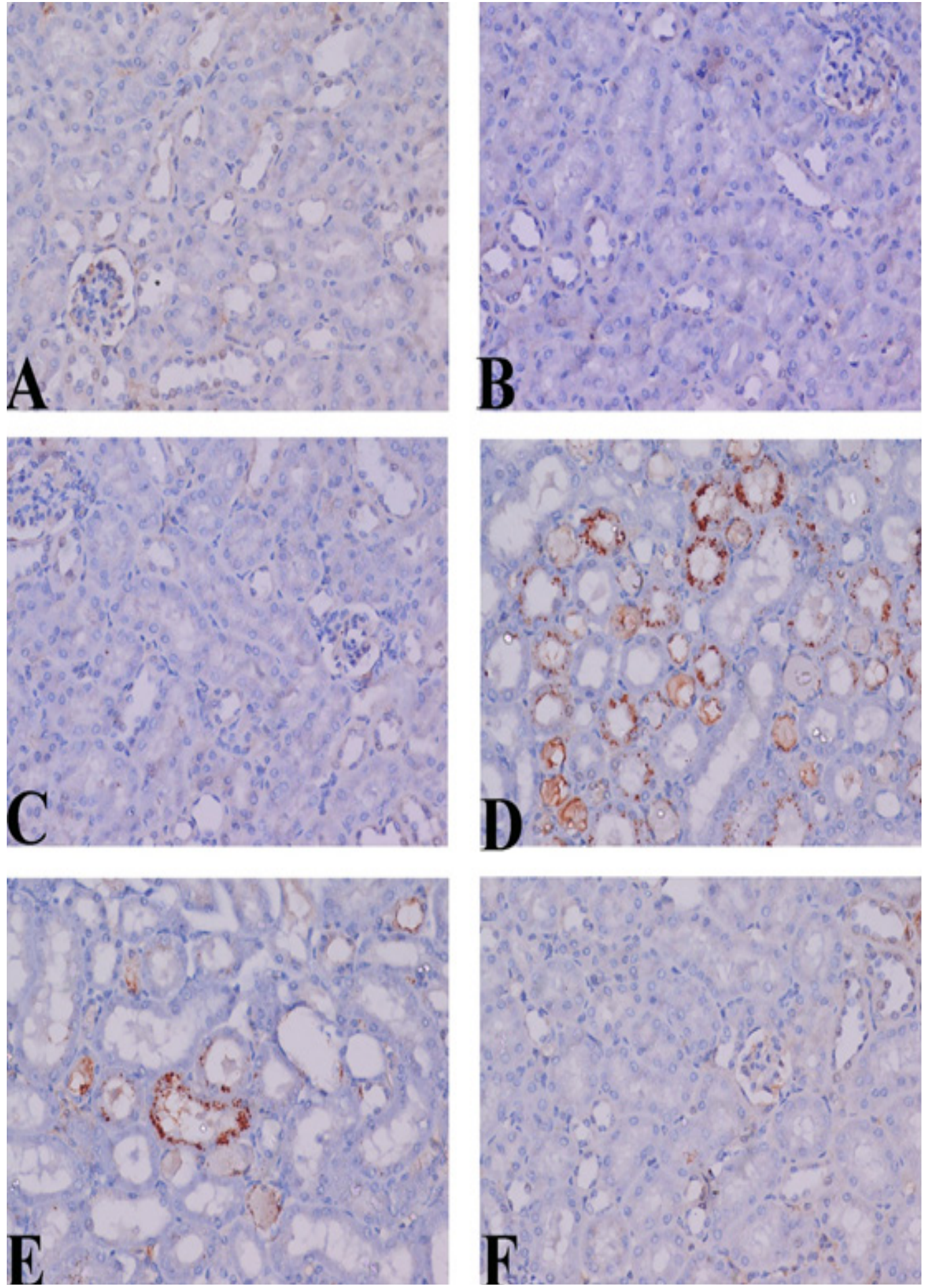

Fig. 4: Photomicrgraphs of renal sections of albino mice A) a section of control group. B) a section of black tea group C) a section or green tea group D)a section of oxalate group shows a highly positive reaction ( dark brown colour) in the renal tubular cells. E) a section of oxalate plus black tea shows a reduction in the immune - reaction in the renal tubular cells and F) a section of oxalate plus green tea group shows a very weak reaction in the renal tubular cells. 


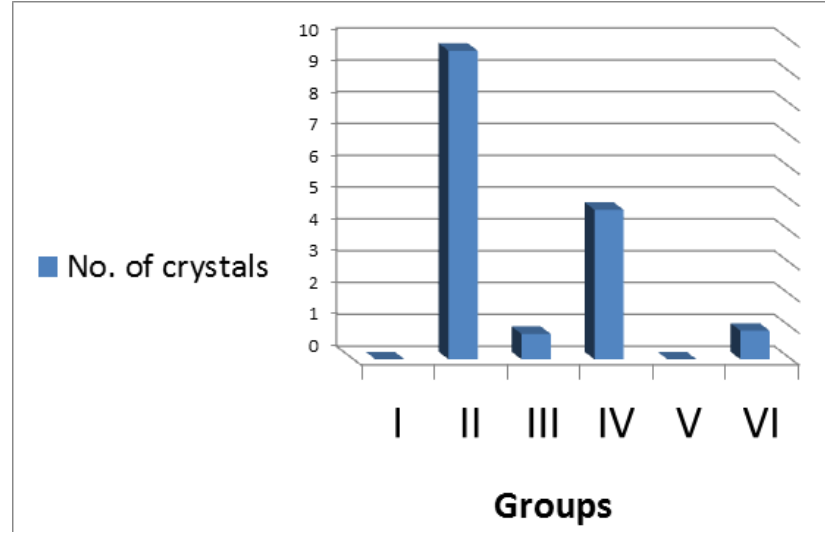

Histogram 1: showing the means of oxalate crystals in the experimental groups

Table 1: Means of area $\%$ of $\mathrm{iNOS}$ and NF-KB in the experimental groups

\begin{tabular}{ccc}
\hline Group & $\begin{array}{c}\text { Means of area\% of iNOS } \\
\text { immune- reaction } \pm \text { SD }\end{array}$ & $\begin{array}{c}\text { Means of area\% of NF- } \\
\text { kBimmune- reaction } \pm \text { SD }\end{array}$ \\
\hline I & $1.42 \pm 1.25$ & $2.47 \pm 1.07$ \\
II & $28.60 \pm 11.85^{\circ}$ & $19.17 \pm 6.09^{\circ}$ \\
III & $1.45 \pm 0.79$ & $2.46 \pm 1.20$ \\
IV & $7.19 \pm 1.19^{\square}$ & $9.07 \pm 1.36^{\square}$ \\
V & $1.30 \pm 1.10$ & $1.83 \pm 1.21$ \\
VI & $3.79 \pm 2.41^{\square}$ & $2.14 \pm 1.14^{\square}$ \\
\hline
\end{tabular}

$\circ P<0.05$ as compared to group I $\quad \square P<0.05$ as compared to group II

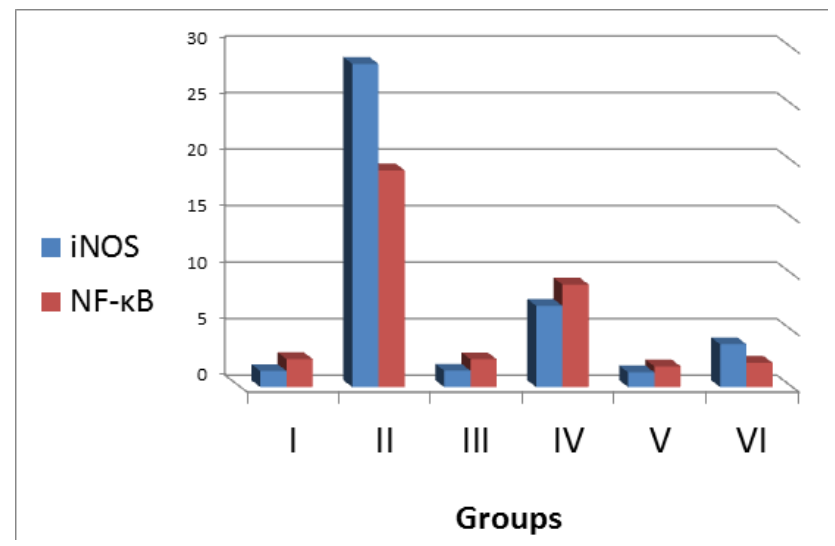

Histogram 2: showing the means of area $\%$ of iNOS and NF- $\mathrm{BB}$ in the experimental groups

Table 2: Serum level of urea and creatinine in the experimental groups

\begin{tabular}{ccc}
\hline Group & $\begin{array}{c}\text { Means of serum urea } \\
\pm \mathrm{SD}\end{array}$ & $\begin{array}{c}\text { Means of serum creatinine } \\
\pm \mathrm{SD}\end{array}$ \\
\hline I & $71 \pm 2.63$ & $0.69 \pm 0.06$ \\
II & $335.6 \pm 12.07^{\circ}$ & $1.93 \pm 0.03^{\circ}$ \\
III & $76.6 \pm 3.19$ & $0.72 \pm 0.01$ \\
IV & $243.4 \pm 9.9^{\circ}$ & $1.59 \pm 0.01^{\square}$ \\
V & $56.2 \pm 2.11$ & $0.68 \pm 0.02$ \\
VI & $218.4 \pm 8.69^{\square}$ & $1.47 \pm 0.031^{\square}$ \\
\hline
\end{tabular}

$\circ P<0.05$ as compared to group I $\quad \square P<0.05$ as compared to group II

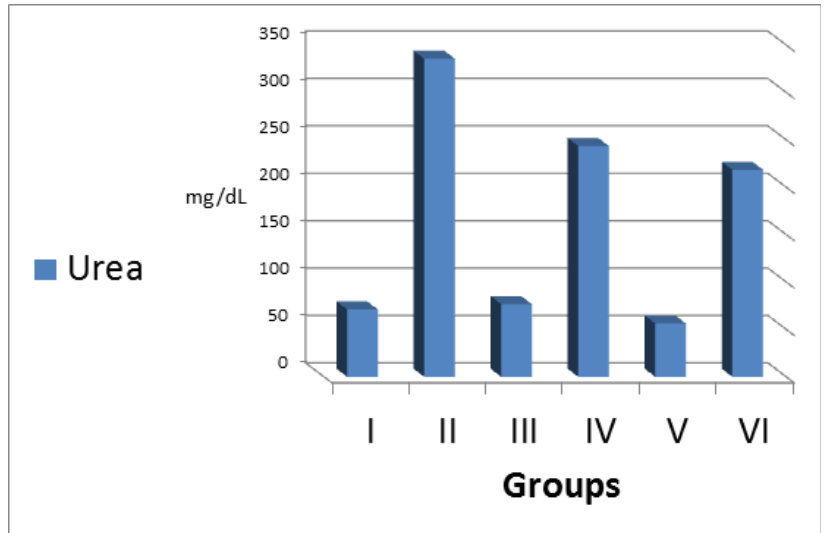

Histogram 3: showing serum levels of urea in the experimental groups

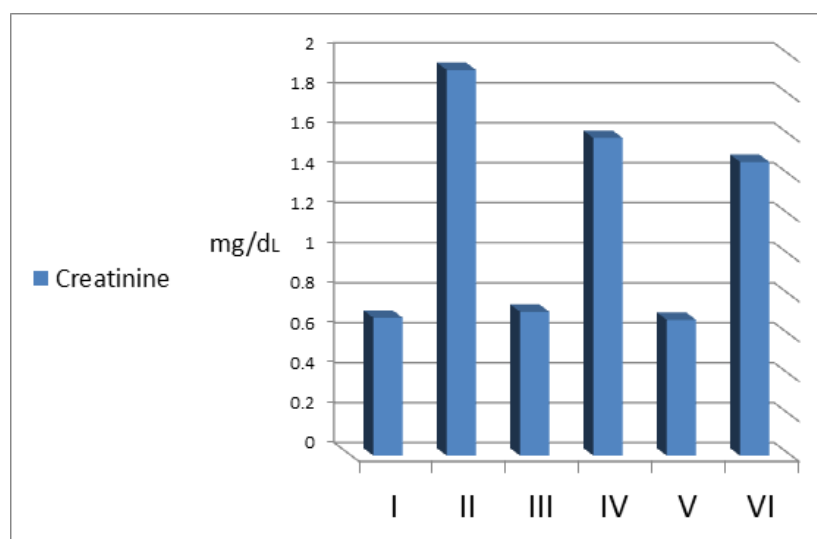

Histogram 4: showing serum levels of creatinine in the experimental groups

\section{DISCUSION}

Persistent hyperoxaluria can cause nephrocalcinosis which means retention of calcium oxalate in the tubules of the kidneys. If the condition not treated, it may progress to nephrolithiasis and renal parenchymal disease (RPD). RPD is characterized by an accumulation of calcium oxalate crystals everywhere in the renal parenchyma with an intense tubular injury. The profound hyperoxaluric renal affection is called hyperoxaluric nephropathy manifests clinically as acute or chronic renal failure that may proceed to end-stage renal disease ${ }^{[20]}$. Experimental hyperoxalurea could be induced by sodium oxalate administration ${ }^{[21]}$.

In the present study, Intraperitoneal injection of sodium oxalate to mice caused a significant increase in serum urea and creatinine indicating a significant functional impairment of the kidney. Serum creatinine concentration is a more potent indicator than the urea in the early stadium of kidney disease. Urea levels in blood commence rising only following parenchymal injury ${ }^{[22]}$. The histological structure of the kidneys of mice intraperitoneally injected with sodium oxalate could explain the aforementioned rise in the kidney function parameters, creatinine and urea. Marked renal tubular damage was seen and the oxalate crystals appeared in the lumina of the tubules. PAS stained sections also revealed damaged brush border and interrupted basal lamina of the renal tubules. The previous 
studies on ethylene glycol induced hyperoxalurea showed renal tubular dilatation with epithelial damage in rats ${ }^{[17]}$. The tubular dilatation was not profound and not affecting the majority of the tubules, in the present study ,may be due to the short period of exposure to oxalate. The tubular cellular damage without dilatation indicated that the oxalate crystals were injurious to the renal tubular cells even in the absence of tubular obstruction. A previous in vitro study by Jeong B.C. et al stated that as the oxalate concentration increased, the number of surviving cells decreased ${ }^{[23]}$. Recently, It is well known that calcium oxalate crystals can produce cellular and/or tissue injury by provoking interruption to cell membranes, generation of lipid mediators (leukotrienes and prostaglandins ), and excess creation of reactive oxygen species, all of which result in an imbalance between antioxidants and oxidants, with mitochondrial malfunction. Furthermore, other studies have shown that calcium oxalate crystals may cause phosphatidylserine imbalance in the cellular membrane and higher production of cell death signals, ceramide ${ }^{[24,25]}$.

In the current study, the pretreatment with the extract of green tea ameliorated the noxious effect of sodium oxalate.The serum urea and creatinine manifested a significant decline as compared to the oxalate group. Moreover, the histological sections stained with H\&E stain and PAS stain revealed that green tea pretreatment alleviated tubular degeneration and caused a substantial reduction in the oxalate crystals. Itoch y. et al reported that co-administration of green tea in drinking water or as a powder with ethylene glycol (hyperoxaluric material) showed a significantly diminished number of calcium oxalate deposits by quantitative evaluation ${ }^{[26]}$. Furthermore, Milica $V$. et al postulated that administration of green tea extract with gentamycin mitigated not only the tubular degeneration induced by gentamycin but also the infiltrations by inflammatory cells and the glomeruli seemed normal in the histological sections ${ }^{[27]}$. Green tea extract could significantly enhance antioxidant protective mechanism in rat kidney by increasing catalase activity. Its catechins have antioxidant characteristics and are powerful scavengers of hydroxyl free radicals ${ }^{[28]}$. The most plentiful catechin in tea is epigallocatechin-3-gallate. It prevents renal damage by aiding in the removal of uremic toxins. Catechins react with $\mathrm{H}_{2} \mathrm{O}_{2}$ in the cellular membrane through a single electron transfer and deprotonation. They also enhance the transcription of phase 2 detoxifying enzymes which serves as an antioxidant response ${ }^{[29]}$ and $^{[30]}$.

Controversy encompasses the issue of whether black tea consumption raises urinary oxalate crystals or not. A number of researches ${ }^{[31-33]}$ had supported the idea that soluble oxalate is absorbed more significantly than insoluble oxalate. Therefore, it has been proposed that black tea had a notable amount of soluble oxalates and could increase the risk of oxalate stone production due to an increase in the discharge of urinary oxalate ${ }^{[34]}$. On the other hand, it should be acknowledged that the affirmation that black tea intake leads to an essential elevation in urinary oxalate concentrations is based on results from a very limited number of studies ${ }^{[35-36]}$. Moreover, Liebman M. and Murphy S. suggested that black tea-derived oxalate is of low bioavailabilityy ${ }^{[37]}$. Additionally, 2 prospective studies reported an association between the intake of tea and decreased risk of renal stones in both males ${ }^{[38]}$ and females ${ }^{[39]}$.

In the present study, Intraperitoneal injection of sodium oxalate to mice that were pretreated with black tea extract produced a significant reduction in serum creatinine and urea.The histological examination revealedcongestion of the renal tissue andThe renal tubular damage was mild. The oxalate crystals could be seen in the tubular lumina but they were significantly reduced in number when compared with the sections of the oxalate group. Also PAS stained sections showed a prominent improvement in the renal structure with black tea pretreatment.The results of the current study could endorse not only the assumption of low bioavailability of black tea -derived oxalate but also the potential positive effects of black tea consumption and its few associated risks. Furthermore, Liebman M. and Murphy S. postulated that there was a little support for the recommendation that kidney stone formers limit their consumption of black tea ${ }^{[37]}$. The protective effect of black tea on renal tissue may be due to the antioxidant effect of tea catechins or the increase in urinary volume ${ }^{[40]}$.

Once inducible nitric oxide synthase enzyme (iNOS) is activated in cells, a substantial amount of nitric oxide (NO) is generated. $\mathrm{NO}$ combines with $\mathrm{H}_{2} \mathrm{O}_{2}$, which creates intermediary products of oxidative stress ${ }^{[41]}$. Therefore, iNOS expression in immunohistochemical investigations has been utilized as a marker of oxidative stress. iNOS was first cloned and distinguished in macrophages, though its activity has been determined in a diversity of cell types ${ }^{[42]}$. In the current study, oxalate injection to mice elevated iNOS expression. Additionally, Black and green tea extracts pretreatment significantly reduced the expression of iNOS in the kidneys.

NF-kB is considered a crucial inflammatory transcription factor that has a fundamental role in the signaling pathway for inflammation in various pathological states. NF-kB signaling mechanism is demonstrated to play a significant role in the renal injury caused under the influence of different agents. NF-kB activates several inflammatory genes resulting in cellular degeneration. At resting normal state, NF-kB is inactive due to its binding with its specific inhibitor (IkB) in the cell cytoplasm. Yet, generation of inflammatory cytokines initiates the NF-kB signaling mechanism ${ }^{[43]}$, after the degradation of $\mathrm{IkB}^{[44]}$. The activated NF-kB is transported to the nucleus and triggers the transcription of many genes such as IL- 6 and TGF- $\beta 1^{[45]}$. These proteins, in turn, provoke multiple reactions, including nitric oxide (NO) overproduction, creation of free radicals, stimulation of apoptotic mechanisms and enhanced generation of extracellular matrix proteins, thus leading to renal injury ${ }^{[46,47]}$. Administration of Black and green tea extracts to mice exposed to renal toxicity by 
oxalate injection, effectively down-modulated the increase in NF- kB expression, compared with oxalate intoxicated counterpart group.

\section{CONCLUSION}

Sodium oxalate caused a deleterious histological and immmunohistochemical alterations in mice' kidney which coincided with elevated renal biochemical parameters. Black and green tea extracts could ameliorate sodium oxalate-induced nephrotoxicity most probably due to their antioxidant characters. Therefore, the earlier recommendations to patients suffering from hyperoxaluric renal diseases and oxalate stone former patients to limit their consumption of tea and dietary supplements containing tea should be changed.

\section{CONFLICT OF INTEREST}

There are no conflicts of interest

\section{REFRENCES}

1. Khan S R .Hyperoxaluria-induced oxidative stress and antioxidants for renal protection. Urological Research. 2005;33 (5): 349-357.

2. Holmes R P, Ambrosius W T ,Assimos D G. Dietary oxalate loads and renal oxalate handling . Journal of Urology.2005; 174 (3): 943-947.

3. Knight T F, Sansom S C, Senekjian H O, Weinman E J. Oxalate secretion in the rat proximal tubule. TheAmerican Journal of Physiology.1981; 240 (4): F295-F298.

4. Robertson W G, Hughes H. Importance of mild hyperoxaluria in the pathogenesis of urolithiasisnew evidence from studies .the Arabian Peninsula in Scanning Microscopy. 1993; 7 (1): 391-402.

5. Vervaet B A, Verhulst A, D'Haese P C,DeBroe $M$ E.Nephrocalcinosis: New insights into mechanisms and consequences . Nephrology Dialysis Transplantation.2009; 24 (7): 2030-2035.

6. Prasad K, Sujatha D ,Bharathi K. Herbal drugs in urolithiasis - A review . Phcog Rev. 2007; $1: 175-179$.

7. Saigal C S, Joyce $\mathrm{G}$,Timilsina A R. Urologic Diseases in America Project: Direct and indirect costs of nephrolithiasis in an employed population: Opportunity for disease management . Kidney Int.2005; 68: 1808-1814.

8. Curhan G C, Willett W C, Rimm E B, Spiegelman D , Stampfer M J. Prospective study of beverage use and the risk of kidney stones . Am J Epidemiol.1996;143: 240-247.

9. Curhan G C, Willett W C, Speizer F E ,Stampfer MJ. Beverage use and risk for kidney stones in women . Ann Intern Med.1998; 128: 534-540.
10. Ferraro P M, Taylor E N,Gambaro G , Curhan G C. Soda and Other Beverages and the Risk of Kidney Stones . Clin J Am SocNephrol .2013; 8: 1389-1395.

11. Gomes A, Vedasiromoni J R, Das M, Sharma R M , Ganguly D K. Anti-hyperglycemic effect of black tea (Camellia sinensis) in rat. Journal of Ethnopharmacology.1995;45 : 223-226.

12. Oyejide O, Olushola L.Hepatoprotective and antioxidant properties of extract Of Carmelliasinensis (black tea) in mice.African Journal of Biotechnology.2005;4 (11): 1432-1438.

13. SelvamR ,Kurien T B. Induction of lipid peroxidation by oxalate in experimental rat urolithiasis . Journal of Biosciences.1987; 12 (4): 367-373.

14. Khan S R, Finlayson B, Hackett R L. Experimental calcium oxalate nephrolithiasis in the rat.Am $\mathrm{J}$ Pathology .1982;107(1): 59-69.

15. Bancroft J, Gamble A. Theory and practice of histological techniques. $6^{\text {th }}$ ed. New York, London: Churchill Livingstone. 2008; 165-175.

16. Kiernan JA. Histological and histochemical methods. theory and practice. $3^{\text {rd }}$ ed. London. New York and New Delhi. Hodder Arnold. 2001.

17. Mousa-Al-Reza H, AbolfazlKhajavi R, Ziba R, Maryam T, Nahid M. The preventive effect of N-butanol fraction of Nigella sativa on ethylene glycol-induced kidney calculi in rats Pharmacogn Mag.2011; 7(28): 338-343.

18. Bowers L D. Kinetic serum creatinine assays. The role of various factors in determining specificity. Clinical Chemistry.1980; 26: 551-554.

19. Richterich $\mathrm{R}$, Kuffer $\mathrm{H}$. The determination of urea in plasma and serum by a urease/ Berthelot method.KlinBiochemistry .1973; 11: 553-564.

20. Robert H G, Yijuan S, Bruce L H, Konstantin N K, Marc B, Joanna R F, Larry M , Antonios H T. Nephropathy in dietary hyperoxaluria: A potentially preventable acute or chronic kidney disease . World J Nephrology.2014; 3(4): 122-142.

21. Parks J H, Fredric L C, Asplin J R. The Pathogenesis and Treatment of Kidney Stones . N Engl J Medicine.1992; 327:1141-1152.

22. Tavafi M, Ahmadvand H, Toolabi P. Inhibitory effect of Olive Leaf Extract on gentamicin-induced nephrotoxicity in rat. Iran J. Kidney Dis. 2012; $6: 25-32$

23. Jeong B C, Kim B S, Kim J, Kim H H. Effects of green tea on urinary stone formation: an in vivo and in vitro study. J Endourology.2006; 20(5): 356-361. 
24. Bigelow $\mathrm{M} \mathrm{W}$, Wiessner $\mathrm{J} \mathrm{H}$, Kleinman $\mathrm{J}$ $G$ and Mandel N S. Surface exposure of phosphatidylserine increases calcium oxalate crystal attachment to IMCD cells .American Journal of Physiology .1997; 272 (1): 55 - 62.

25. Cao L C, Jonassen J, Honeyman $\mathrm{T}$ W , Scheid C. Oxalate-induced redistribution of phosphatidylserine in renal epithelial cells: implications for kidney stone disease. American Journal of Nephrology.2001; 21 (1): 69-77.

26. Itoch Y, Yasui T, Okada A, Tozawa K, Hayashi Y , Kohri K. Preventive effects of green tea on renal stone formation and the role of oxidative stress in nephrolithiasis.J Urol. 2005; 173 (1): 271-275.

27. MilicaV, Dragana R P, Nenad S, Sonja I, Aleksandar P, Ivan J , Mirjana R. Morphological and morphometric study of protective effect of green tea in gentamicin-induced nephrotoxicity in rats . Life Sciences .2016; 147: 85-91.

28. AdeneyeA A, Benebo A S. Protective effect of the aqueous leaf and seed extract of Phyllanthusamarus on gentamicin and acetaminophen induced nephrotoxic rats. J. Ethnopharmacology . 2008;118: 318-323.

29. Elhalwagy M E A., Darwish N S ,Zaher E M. Prophylactic effect of green tea polyphenols against liver and kidney injury induced by fenitrothion insecticide.Pestic. Biochem. Physiology.2008; 91: 81-89.

30. Kalayarasan S, Prabhu P N, Sriram N, Manikandan R, Arumugam M, SudhandiranG.Diallylsulfide enhances antioxidants and inhibits inflammation through the activation of Nrf2 against gentamicininduced nephrotoxicity in Wistar rats. Eur.J. Pharmacology .2009; 606: 162-171.

31. LiebmanM, Chai W. Effect of dietary calcium on urinary oxalate excretion after oxalate loads . Am J Clin Nutrition .1997; 65:1453- 1459.

32. Chai W ,Liebman M. Assessment of oxalate absorption from almonds. and black beans with and without the use of an extrinsic label. J Urology.2004; 172: 953 - 957.

33. BrogrenM, Savage G P. Bioavailability of soluble oxalate fromspinach eaten with and without milk products . Asia Pac J Clin Nutrition.2003; 12: $219-224$.

34. McCay D W, Seviour P, Comerford A, Vasdev S, Massey L K.Herbaltea: an alternative to regular tea for those who form calcium oxalate stones . J Am Diet Association. 1995; 95: 360- 361.

35. Finch A M, Kasidas G P , Rose G A. Urine composition in normalsubjects after oral ingestion of oxalate-rich foods .ClinScience .1981; 60: $411-418$.

36. Savage G P, Charrier M J S, Vanhanen L. Bioavailability of solubleoxalate from tea and the effect of consuming milk with the tea .Eur J Clin Nutrition.2003; 57: 415- 419.

37. LiebmanM, Murphy S. Low oxalate bioavailability from black tea .Nutrition Research.2007; 27: $273-278$.

38. Curhan G C, Willett W C, RimmE B, Spiegelman D, Stampfer M J. Prospective study of beverage use and the risk of kidney stones. Am J Epidemiology.1996;143: 240-247.

39. Curhan G C, Willett W C, Speizer F E, Stampfer M J. Beverage use andrisk for kidney stones in women . Ann Intern Med.1998;128: 534- 540.

40. Massey L K. Tea oxalate. Nutr Rev.2000; 58: 88- 89 .

41. Viaro F, NobreF, Evora P R. Expression of nitric oxide synthases in the pathophysiology of cardiovascular diseases . J Arq Bras Cardiol.2000;74: 380-393.

42. Asmaa A, Kattaia A, Samia A A. Effect of bisphenol A on the lung of adult male albino rats and the possible protective role of geraniol: a histological and immunohistochemicalstudy. The Egyptian Journal of Histology .2014; 37: 24-35.

43. GuijarroC ,Egido J. Transcription factor-kappa B (NF-kappa B) and renal disease . Kidney Int.2001;59: 415- 424.

44. Traenckner E B, Pahl H L, Henkel T, Schmidt K N, Wilk S , Baeuerle P A. Phosphorylation of human I kappa B-alpha on serines 32 and 36 controls I kappa Balpha- proteolysis and NF-kappa $\mathrm{B}$ activation in response to diverse stimuli . EMBO J.1995,14: 2876-2883.

45. Yang B, Hodgkinson A, Oates P J, Millward B A ,Demaine A G.High glucose induction of DNA-binding activity of the transcription factor NFkB in patients with diabetic nephropathy in Biochim. Biophys.Acta Mol. Basis Disease.2008; 1782: 295-302.

46. McCarthy E T, Sharma R, Sharma M, Li J Z, Ge X L, Dileepan K N ,Savin V J. TNF-alpha increases albumin permeability of isolated rat glomeruli through the generation of superoxide. J. Am. Soc. Nephrology.1998; 9: 433- 438.

47. Alnahdi H. Bovine Lactoferrin Attenuates Renal Damage Induced by Nicotine Toxicity by Blocking Nuclear Factor Kappa-B Signaling Mechanisms. eIJPPR.2017; 7(6): 24-30. 
الملخص العربى

تأثير مستخلص الثاي الأسود والأخضر على التسمم الكلوي الناتج عن اوكسالات الصوديوم بالفئران الانئ

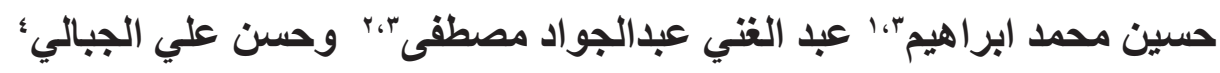

'قسم التشريح وعلم الاجنة ــلية الطب ـ جامعة عين شمس-القاهرة-مصر

بقسم الهستولوجي - كلية الطب - جامعة الازهر- دمياط ـ مصر

"قسم علوم المختبرات الاكلينيكية ـ كلية العلوم الطبية التطبيقيةـ جامعة الجوف ـ سكاكاـ السعودية

قُقم الاحياء - كلية العلوم- جامعة الجوف - سكاكاـ السعودية

المقدمة:الاوكسالات هو عنصر متوفر في الأطعمة من أصل نباتي.التركيزات المرتفعة للاوكسالات في البول تؤدي

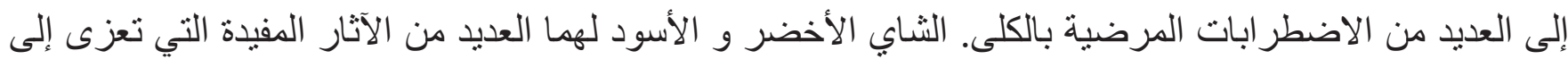

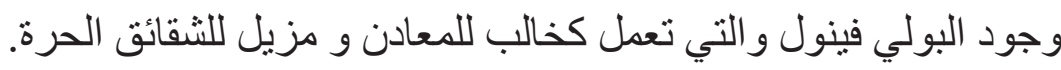
الهُف: تهدف هذة الدر اسة إلى توضيح التأثثر المحسن المحتمل للثاي الاسود و والاخضر على تلى تلف انسجة الكلى الناتج عن الاوكسالات. مواد وطرق البحث: تم تقسيم ثناثين من الفئر ان الذكور إلى ست مجموعات : المجمو عة الاولى (الضابطة)، المجمو عة

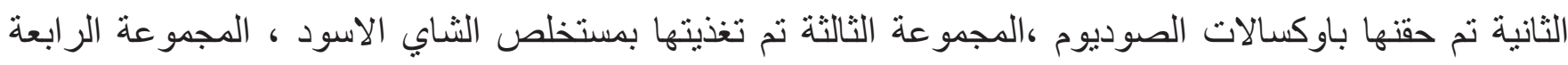

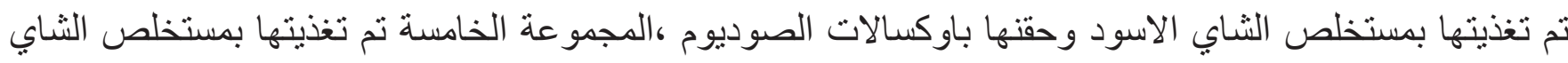

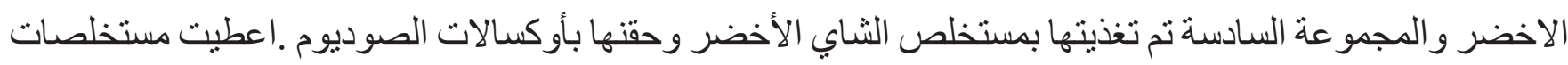
الثاي الأسود و الاخضر بجرعة 2ملي/100 جر ام باليوم لمدة 10 أيام. بينما تم حقن اوكسالات الصوديوم داخل

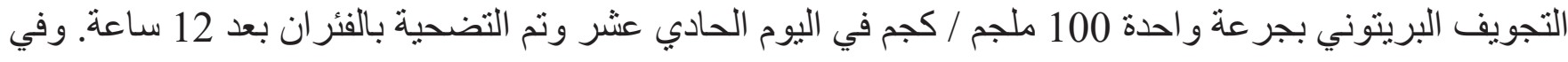
نهاية التجربة تم الحصول على عينات من الدم و الكلي من جميع المجموعات. ونم إجر اء تحليل اليوني اليوريا والكرياتينين

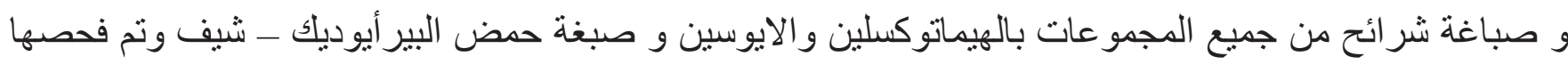
بالمجهر الضوئي. كما تم عمل صبغات هستوكيميائية مناعية باستخدام أجسام ضد iNOS و و الدار اسات القياسية للشر ائح. النتائج:اظهرت النتائج تحلل وموت بخلايا الكلى بمجمو عة الاوكسالات كما اظهرت توسع بالانابيب الكلوية ،وتكتلات بروتينية و بلور ات الاوكسالات الثفافة وتقطع بالسطح الفرشي و الصفائح القاعدية لانابيب الكلى.علاوة على ذابلى ذلك كانت

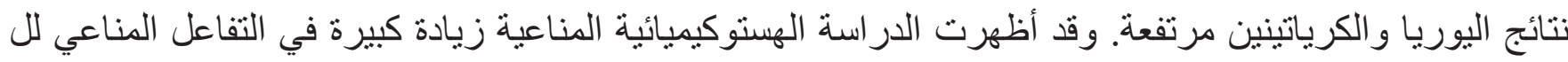
وقد تحسنت التغير ات السابق ذكر ها في المجمو عات الر ابعة و السادسة.

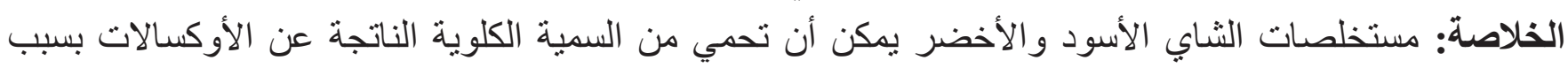
خصائصهم المضادة للأكسدة. 